\title{
A CONSTRUÇÃ̃ DO IDEÁRIO REPUBLICANO: A VIDA ATIVA E A DEFESA DA LIBERDADE
}

\author{
Elivanda de Oliveira Silva ${ }^{1}$ \\ Universidade Federal de Minas Gerais (UFMG)
}

\section{RESUMO:}

O principal objetivo deste texto é compreender os conceitos fundamentais que constituíram o que hoje chamamos de tradição republicana e cotejá-los com o sentido de política que fundamenta as atuais sociedades democráticas liberais. A proposta tem como percurso teórico a análise de um conjunto de temas políticos que serviram de alicerce para a construção do ideário republicano que os estudiosos contemporâneos chamarão de Republicanismo.

PALAVRAS-CHAVE: Política; Tradição republicana; Ideário republicano; Republicanismo.

\section{THE CONSTRUCTION OF THE REPUBLICAN IDEALS: THE ACTIVE LIFE AND THE FREEDOM DEFENSE}

\begin{abstract}
:
The main aim of this paper is to understand the fundamental concepts that were part of what we all nowadays as the republican tradition and collate them with the sense of politics that underpins the current liberal democratic societies. The proposal has as a path of theoretical analysis a set of political themes that served as the foundation for the construction of republican ideals which contemporary scholars will call as republicanism.
\end{abstract}

KEYWORDS: Politics; Republican Tradition; Republican Ideals; Republicanism.

1 Doutoranda em Filosofia pela Universidade Federal de Minas Gerais (UFMG), Minas Gerais Brasil. E-mail: elivandaos@gmail.com

SILVA, Elivanda de Oliveira. A construção do ideário republicano: a vida ativa e a defesa da liberdade. Griot : Revista de Filosofia, Amargosa, Bahia, v.16, n.2, p.236-252, dezembro/2017. 


\section{Introdução}

O principal objetivo deste texto é fazer uma análise dos elementos políticos que serviram como alicerce de construção do ideário republicano que os estudiosos contemporâneos chamarão de Republicanismo. $O$ vocábulo ideário é uma sugestão de Alberto de Barros ${ }^{2}$, o qual decidimos acolher por acharmos mais adequado que os termos origem, nascimento, fundação, uma vez que são muitas as matrizes ${ }^{3}$ que explicitam o Republicanismo e caso decidíssemos por uma explanação mais pormenorizada de todas essas vertentes, correríamos o risco de ampliar demasiadamente nossa investigação, afastando-nos do objetivo principal da discussão.

Nesse sentido, a fim de evitarmos um grande equívoco, devemos alertar ao nosso leitor que não pretendemos realizar uma história do Republicanismo ou de todas as matrizes que o fundamentam. $O$ que almejamos é compreender os conceitos fundamentais que constituíram aquilo que hoje chamamos de tradição republicana e cotejá-los com o sentido de política que fundamenta as atuais sociedades democráticas liberais.

No percurso de desvelamento do ideário republicano, acreditamos que a contribuição e o legado de Cícero são fundamentais, uma vez que sua obra política contribuiu com a consolidação de problemas e temas especificamente republicanos, bem como porque muitas das questões apresentada por ele serão posteriormente retomadas pela tradição republicana que se forjará com o Humanismo cívico, no Renascimento italiano, e, na contemporaneidade, com os novos republicanos. Portanto, a primeira seção deste artigo apresentará uma discussão sobre um conjunto de temas que constituem o núcleo do ideário republicano, tais como: amor à pátria, a defesa da liberdade e a importância do ato fundador como instante originário da identidade da melhor forma política de uma cidade, os quais já se encontram na filosofia política de Cícero.

Sob o impacto das obras de Cícero e de outros autores romanos, a saber: Salústio, Tito Lívio, Tácito, esses temas serão retomados pela primeira geração de humanistas, da qual Petrarca e Salutati são alguns de seus expoentes. O problema que eles enfrentaram era o de definir um caminho que pudesse, ao mesmo tempo, manter os vínculos com a vida cristã e afirmar os valores cívicos exaltados por Cícero, os quais eram imprescindíveis para preservar a liberdade das cidades-estados italianas, que passavam por momentos de instabilidade. A primazia da vida pública sob a contemplativa será decisiva na compreensão do nascimento de uma nova maneira de conceber o homem e sua relação com o mundo. Esse será o mote de discussão da segunda seção deste artigo.

\footnotetext{
2 "Não é tarefa das mais simples enunciar o ideário republicano. Como outras doutrinas políticas, o republicanismo não teve sua origem nem encontrou sua formulação definitiva num único autor ou num único período. Por ter sido construído por diferentes autores no decorrer dos séculos, possui as diversas matrizes, manifestando-se de várias maneiras na história do pensamento político"(BARROS, 2015 , p.36).

${ }^{3}$ Newton Bignotto sugere que há pelo menos cinco matrizes que explicitam o republicanismo: matriz romana, matriz, italiana, matriz inglesa, matriz francesa, matriz norte-americana (BIGNOTTO, 2013, p.10).
}

SILVA, Elivanda de Oliveira. A construção do ideário republicano: a vida ativa e a defesa da liberdade. Griot : Revista de Filosofia, Amargosa, Bahia, v.16, n.2, p.236-252, dezembro/2017. 
Os ideais republicanos alcançarão maior notoriedade a partir dos escritos políticos de Maquiavel que, em virtude de sua importância e contribuição para pensarmos os problemas concernentes à vida pública, foi consagrado como o maior expoente do Republicanismo moderno. Contudo, salienta Quentin Skinner, em Liberdade antes do Liberalismo, que se no século XIV, a teoria republicana atingiu seu auge, na Modernidade, com o surgimento do Liberalismo e a justificação de princípios utilitaristas para fundamentar o Estado, o que se constatou foi o declínio das ideias republicanas, como discutiremos no último tópico do artigo.

\section{As virtudes cívicas e a construção da Res publica: o legado de Cícero}

Investigar a forma como os autores da tradição de pensamento clássico pensaram a política e suas instituições é significativo na medida em que nos permite conhecer os motivos da necessidade da ação política, da criação do novo, da exaltação de determinados valores e comportamentos que têm a pretensão de representar a comunidade cívica idealizada. Partindo desse pressuposto, consideramos que, na Antiguidade Clássica, houve a preocupação em conceber um modelo de vida e de homem que expressaria, sobretudo, a uirtus adequada de um corpo político harmonioso. Esse movimento de construção da melhor forma de governo da cidade, que já havia sido discutido por Platão e Aristóteles, encontra em Cícero uma renovação original, a ponto de entendermos que ele é um autor basilar no que se refere à compreensão da construção do ideário republicano.

Não é sem propósito, que a todo instante, em sua obra De República, nos deparemos com expressões, tais como homem ativo, assuntos comuns, negócios públicos, unidade do povo, apoio comum para demarcar não somente um espírito cívico, mas também uma esfera de ação típica de homens que, movidos pela coisa pública, a ela se sentem pertencentes. Esses princípios, que foram inspirados em fontes gregas, através do contato com as obras políticas de Aristóteles e dos estóicos, e, também, a partir da história e da experiência política romana, já apontam, de certo modo, para valores republicanos que nenhum governo que se pretende republicano pode deixar de exaltá-los, sob pena de ser descaracterizado.

Nos primeiros livros de De Republica, Cícero nos oferece uma defesa magnífica da virtude política como exigência primeira daqueles que desejam se dedicar à vida pública, contrapondo-a a um modo de vida defendido pelos sábios. Para Cícero, nenhuma ciência, nenhum conhecimento pode ser mais nobre que a virtude quando expressa no amor à pátria e à conservação da república. A defesa de Cícero é que "a vida ativa ou política está acima da vida contemplativa e exalta a virtude prática, especialmente a que consiste no governo da república" (TURSI, 2010, p.93). A virtude civil é expressa pelo comprometimento dos cidadãos com os negócios públicos e é "o verdadeiro significado do ideal republicano do amor pela pátria" (VIROLI, 2007, p.11). Ela é necessária, "exatamente porque o principal fim dos Estados é refrear os arrogantes, os ambiciosos e os viciosos", o que por sua vez, exige "que os cidadãos saibam e queiram manter a mão sobre a liberdade" (VIROLI, 2007, p.08).

Cícero defende que os bons cidadãos devem estar atentos e preparados para participar das magistraturas, o que, por conseguinte, evitaria que os maus a tomem 
em benefício próprio. Os bons cidadãos são, portanto, aqueles que, tomados pelo amor pátrio e movidos por sentimentos públicos, são capazes de conter seus interesses particulares e agir visando o interesse comum, o cuidado com a coisa pública e o fortalecimento de instituições que garantam o direito do povo de participar dos negócios da cidade (CÍCERO, 2011, p.13-14).

O que realmente importava a Cícero era a constituição e conservação da República, tarefa que muitas vezes requer o sacrifício do próprio bem-estar em prol do bem público: "A constituição de uma República", diz Cícero, é a "maior obra do gênio humano sobre a terra" (CICERO, 2011, p.79), e é o que define o cidadão ativo, que deve preferir o exame atento das ações que se sucedem na República, a assuntos sem relevância pública.

Cícero define República como coisa do povo, que pertence ao res populi, ou seja, ao povo. E povo não é qualquer congregação de pessoas, mas um conjunto de homens associados por um consenso jurídico (iuris consensus) e pela utilidade comum (utilitas communis) que serve a todos por igual: "A república, coisa do povo, considerando tal, não todos os homens de qualquer modo congregados, mas a reunião que tem seu fundamento no consentimento jurídico e na utilidade comum" (CÍCERO, 2011, p.30). A associação entre os homens, os quais constituirão a república, é justificada não por um instinto de sobrevivência, ou ainda por uma debilidade da natureza humana, mas por causa de uma certa tendência natural de sociabilidade, uma certa disposição, que os levam a uma unidade com vistas a uma vida em comum, cuja motivação encontra-se na utilitas publica, como esclarece Elio Dovere.

\footnotetext{
Na filosofia política de Cícero, a utilitas é igualmente congruente com a essência mesma da legislação: servir communi utilitatis (para a utilidade de todos) tem um lugar preciso nas finalidades da respublica; já que, para o Estado, aquilo que é justo e legitimo é seguramente vantajoso precisamente, a publica utilitas - todos os outros interesses devem ser subordinados a esta última. A utilitas perseguida pelo Estado, por consequência, deve constituir a essência final de cada ato legitimamente realizado. Nessa perspectiva, o interesse público é também o fundamento da justiça, e a utilitas universorum (utilidade geral) só pode se realizar na organização do Estado (DOVERE, 2006, p.110).
}

Para Cícero, uma organização política é identificada como res pública quando as ações do governo, em virtude do seu caráter público, são direcionadas ao povo e para o povo, e quando povo e governo fundamentam suas ações na observância da justiça, no império das leis e na comunhão de interesses: "Se não admite a igualdade da fortuna, se a igualdade da inteligência é um mito, a igualdade dos direitos parece ao menos obrigatória entre os membros de uma mesma república" (CÍCERO, 2011, p.34). Isso implica dizer que nem os tiranos nem as facções ou qualquer governo despótico conseguem estabelecer um ambiente cívico apropriado que atenda a essas exigências, pois "não há felicidade sem uma boa constituição política; não há paz, não há felicidade possível, sem uma sábia e bem organizada República" (CÍCERO, 2011, p.98), e, principalmente, porque "a liberdade [...] só pode existir verdadeiramente onde o povo exerce a soberania; não pode existir essa liberdade, que 
é de todos os bens o mais doce, quando não é igual para todos" (CICERO, 2011, p.333).

Explicitado o significado de República e a importância da virtude política para a sua conservação, Cícero passa a se debruçar sobre o melhor regime que pode corresponder a essa forma de governo. Ele acolhe uma reflexão já realizada pelos filósofos da Grécia Antiga: Platão ${ }^{4}$, Aristóteles ${ }^{5}$ e Políbio ${ }^{6}$. Sob a influência desses pensadores, Cícero aborda três formas de governo: realeza (regnum), aristocracia (optimatium) e governo popular (civitas popularis). Contudo, nenhuma é totalmente virtuosa por si só, o que faz com que todas apresentem inconveniências. Na realeza, o povo não tem direito de participar dos negócios públicos; na aristocracia, o povo é excluído das deliberações e goza de pouca liberdade; no governo popular, a igualdade de direitos acaba por tornar-se injusta ao não levar em consideração o mérito de cada cidadão (CICERO, 2011, p.31). Em virtude dessas restrições, que, por sua vez, geram instabilidades, essas formas de governo acabam por se degenerar em tirania, a qual trata-se de um regime de opressão; oligarquia, que é o domínio de uma facção; e despotismo da multidão, que é o regime da liberdade excessiva (CICERO, 2011, p.45).

A solução do filósofo romano para o problema da corrupção e instabilidade dos regimes políticos, tema clássico do ideário republicano, é o regime misto, o qual ele explicita por intermédio de Cipião: "Por minha parte; creio que a melhor forma política é uma quarta constituição formada da mescla e reunião das três primeiras" (CÍCERO, 2011, p.32). No entendimento de Cícero, o governo misto é a melhor constituição porque além de reunir o que há de melhor das outras três formas de governo, assegura estabilidade ao corpo político e a liberdade aos cidadãos da república.

No segundo livro do diálogo, Cícero afirma que o melhor exemplo dessa mistura é a própria república romana, que se tornou grandiosa por ter conseguido elaborar uma constituição com os melhores princípios de cada uma das formas simples, ao mesmo tempo em que evitou os seus vícios. Ao reconstituir a história da fundação de Roma, Cícero mostra que ela, desde o início, estava carregava de traços de uma constituição mista, tendo em vista que esta não se tratou do fruto da genialidade de apenas um legislador, mas contou com a experiência dos antepassados, a união de diferentes grupos de cidade e a contribuição de cidadãos virtuosos. Isso explica, por exemplo, o sucesso de Rômulo na fundação de Roma, que entendeu "que o poder de um só e a potestade régia é, para os Estados, a melhor forma de constituição, se a ela se acrescentam a autoridade e o apoio dos melhores" (CÍCERO, 2011, p.32).

Isso permite dizer, por um lado, que o objetivo da constituição mista é a união dos diferentes grupos e estratos políticos cuja intenção é estabilizar o corpo político fundado e mantê-lo virtuoso, e, por outro, reconhecer que a fundação não se

\footnotetext{
${ }^{4}$ Para uma análise da constituição do regime ideal em Platão, conferir (PLATÃO, 2006, L.VIII, 544a$569 \mathrm{c})$.

5 Para uma compreensão do ponto de vista Aristotélico para o problema da instabilidade e degeneração dos regimes políticos, sugerimos a leitura de (ARISTÓTELES, 2006, L. III).

${ }^{6}$ Para uma análise mais detalhada da defesa do regime misto em Políbio, conferir (POLIBIO, 1996, L.VI, 3-9).
} 
restringe apenas à criação das leis de um povo, suas instituições, seus costumes, mas também tem como fundamento a própria história que se desenvolve nesse ato fundacional inaugural, o qual deve ser sempre renovado pelos diversos atores que compõem o corpo político, sendo que "a fundação contínua é necessária exatamente porque toda forma política corre o risco de se degenerar, a tal ponto que a ação humana perde sua força criadora, ou dito de uma outra forma, que a fundação não seja mais possível" (BIGNOTTO, 1991, p.166).

No entendimento de Cícero, a grandeza da república romana só foi possível porque os atores políticos que compunham a cena pública da cidade tornaram a fundação de seu corpo político e sua conservação acontecimentos constitutivos da vida pública, destacando, desde o início, a relevância da ação política como condição indispensável da identidade do novo corpo político e o comprometimento da lei em assegurar a liberdade dos cidadãos. É devido a esse valor cívico inerente à fundação que, para ele, não há outra virtude humana que mais se aproxime do nume dos deuses que "fundar novas nações ou conservar as já fundadas" (CICERO, 2011, p.15).

\section{O Humanismo cívico e a defesa da vida ativa}

Hans Baron, em sua obra The Crisis of the early Italian Renaissance, esclarece que os acontecimentos e mudanças que marcaram o ano de 1400, nas cidades-estados italianas, foram decisivos para a compreensão do nascimento de uma nova maneira de conceber o homem e sua relação com o mundo.

O que se faz notar, diz Baron, é que o período de transição do Trezentos para o Quatrocentos foi acompanhado de importantes mudanças na vida pública das cidades italianas, especialmente, em Florença. Uma dessas mudanças, à qual Baron afirma estar vinculada a formação do Humanismo cívico, foi operada pela guerra entre Florença e Milão. Essa guerra se desenrolou a partir de dois eixos antagônicos. Um deles, aquele que consolida os princípios que fundamentam o Humanismo, enxerga em Florença a verdadeira pátria da liberdade. O outro aponta Milão como um governo que, apesar de assegurar a liberdade popular, depende da virtude de seu governante. Os humanistas do Quatrocentos acreditavam que "em nome da liberdade, ou seja, do único valor que torna a vida digna de ser vivida, Florença torna-se a pátria ideal de todos os homens (GARIN, 1996, p.24).

Para Baron, a consequência radical desse processo de instauração de uma nova consciência histórica é que os elementos que haviam sido absorvidos pelo Trezentos foram destruídos ou transformados, cedendo lugar a uma nova concepção de mundo acompanhada pelo ideal de uma sociedade livre (BARON, 1955, p.06).

Esse não é o ponto de vista de Quentin Skinner, que defende, em $A s$ Fundações do Pensamento Político Moderno, a continuidade do ideário republicano entre a Idade Média e o Renascimento. Segundo Skinner, no fim do século XII, a maioria das cidades italianas vivia em clima de tensão, em virtude de acirradas lutas civis entre facções internas, o que as forçou a abandonar suas constituições republicanas e aceitar o poder de um único signori, abdicando de um governo livre para o acolhimento de um despótico, a fim de que a paz cívica fosse atingida (SKINNER, 2006, p.48). Embora os signori tenham tido êxito em várias cidades 
italianas que, exauridas em razão das diversas guerras que estavam enfrentando e, portanto, sem fôlego para se oporem às ações dos tiranos, algumas poucas, como Milão e Florença, ao resistirem à tentativa de controle do poder por parte dos governos hereditários de uma única família "desenvolveram uma aguda consciência do valor que merecia ser dado à independência política e ao governo republicano" (SKINNER, 2006, p.48).

O que Skinner sustenta é que diante desse panorama de lutas civis e do esforço para resistir ao poder dos signori, criou-se no início do Trezentos uma "ideologia política que tinha em mira defender e realçar as virtudes distintivas da vida cívica republicana" (SKINNER, 2006, p.49), o que não foi reconhecido por historiadores do pensamento renascentista, como por exemplo, Hans Baron, que insiste na tese de que somente no início do Quatrocentos houve, por parte dos humanistas cívicos florentinos, uma defesa da liberdade republicana.

O esteio sob o qual se apoia essa leitura de Skinner é o de que o desenvolvimento desse espírito republicano que aflorou nas cidades italianas pode ser observado nos tratados dos dictatores florentinos já no século XII. Estes instrutores da ars dictaminis, ao ensinar modelos de cartas endereçadas a personalidades da cidade (papas, imperador, professores, magistrados), expressavam suas preocupações políticas com os negócios das cidades e faziam das mesmas um veículo fundamental para opinar sobre os problemas da vida urbana. A partir das ars dictaminis (ensino da redação de cartas e documentos oficiais endereçadas a personagens ilustres das cidades) e do ars arengendi (a arte de fazer discursos públicos) que vinham anexados às cartas, os dictatores teriam criado, ao focar suas preocupações nos assuntos cívicos, dois gêneros de escrita política que ressaltavam os ideais republicanos: as crônicas, que exaltavam a defesa da liberdade como o bem mais poderoso para a independência das cidades; e os livros de conselhos, que, por meio da exortação das virtudes cívicas, preparavam os eleitos para exercer os cargos públicos. Assim, esclarece Skinner, o legado mais importante que se observa nos tratados produzidos pelos dictatores é que, em um momento de grande instabilidade política e de avanço do poder dos signori, em que se colocava em xeque os valores republicanos, esses autores reagiram, inaugurando a primeira grande defesa dos valores políticos que constituem uma república. Eles não apenas exaltavam a liberdade como valor preponderante de um governo livre, mas desejavam compreender também os motivos que levam à vulnerabilidade das cidades-repúblicas e os métodos adequados para sanar os conflitos políticos (SKINNER, 2006, p.49-62).

$\mathrm{O}$ fato é que, para além de um marco cronológico ou uma definição precisa, o Humanismo cívico encontra sua legitimidade em um outra dimensão: aquela da ética, do sentido da existência, de uma consciência histórica, do valor do homem e de suas ações sobretudo, porque o que está em questão não é uma volta ao passado, mas "uma afirmação renovada do homem, dos valores humanos, nos vários domínios: desde as artes à vida cotidiana" (GARIN, 1999, p.9). Esses parecem ser os verdadeiros aspectos que confirmam que algo estava renascendo. Esse processo de criação do novo jamais teria sido possível e alcançado os domínios mais elevados da condição humana sem o intenso trabalho de uma geração de humanistas, conhecidos como professores e intelectuais que, não apenas ensinaram os studia humanitati (gramática, retórica, poética, história, filosofia moral), como tornaram-nas tão 
significativas a ponto de reconhecê-las como superior aos demais estudos, exatamente por serem capazes de fazer do saber do homem um saber plenamente humano (TARANTO, 2006, p.200).

Nesse sentido, Eugênio Garin, no seu Ciência e vida civil no Renascimento italiano, argumenta que os autores que não conseguem se desprender de um raciocínio cujo fundamento é pautado em uma continuidade linear para compreender o movimento humanístico se esquecem do fato de "que o movimento humanístico explodiu, partindo da vida civil em direção aos vários campos do saber, permitindo sua retomada e seu florescimento" (GARIN, 1996, p.10). Isso equivale a dizer que a cultura humanística, que desabrochou nas cidades italianas entre os séculos XIV e $\mathrm{XV}$, manifestou-se principalmente no campo das artes, da política, da retórica e da moral, buscando um novo caminho em direção aos autores antigos, e serviu para elaborar uma concepção da vida e de significado do homem na sociedade (GARIN, 1996, p.10). O argumento de Garin é o de que a defesa da liberdade e da vida ativa exige uma nova prática política, que aos poucos deixará para trás a superioridade da vida contemplativa em prol do reconhecimento da vida pública como a instância suprema na qual podem ser manifestados os valores mais elevados da condição humana.

Nesse sentido, a questão que se colocava, então, era a de se uma vida voltada à contemplação, a uma clausura interior, separada dos problemas que são inerentes à condição humana seria mais digna, ou, se seria possível vislumbrar uma nova maneira para enxergar a cidade e os valores associados à vida pública. É nesse contexto que Petrarca, ao mesmo tempo em que fazia elogio à vida cívica, não conseguia se desvencilhar totalmente de suas convicções religiosas, pois ainda sentiase o peso das teses agostinianas nos seus discursos e toda uma influência do mundo medieval ${ }^{7}$. Esse modo de compreender a realidade e a existência humana vigorou fortemente por vários séculos até que o Humanismo italiano, recuperando o pensamento de alguns autores da Antiguidade, permitiu a retomada de uma preocupação com a vida terrena e a gerência dos assuntos seculares pelos próprios homens (BIGNOTTO 1991, p. 9-26).

\footnotetext{
${ }^{7}$ Romper com o passado medieval e fazer da vida ativa o modelo a ser seguido pelos cidadãos, não foi um processo que se desencadeou ao longo do Quatrocentos sem maiores problemas, afinal o que se avistava era a inauguração de um novo paradigma que marcaria definitivamente a relação do homem com a política. $\mathrm{O}$ relato de Petrarca, da subida ao monte Ventoux, que se encontra na primeira carta do quarto livro das Familiares, revela o quanto Petrarca ainda demonstra apego à vida contemplativa, como explica Helton Adverse: "A carta sobre a subida ao Monte Ventoux contém uma forte indicação de qual é a forma de vida que Petrarca considerava a melhor. A valorização da alma e o desprezo pelas coisas terrenas não deixam dúvidas acerca da inferioridade da vida neste mundo. Mas, se esse é um sinal claro da sincera adoção de um modus vivendi altamente valorizado durante a Idade Média, não devemos nos esquecer de que Petrarca tem grande consideração pela cultura clássica. Não se trata de ambiguidade ou de tensão, mas de uma escolha de vida (a cristã) que jamais é vista em oposição à cultura antiga. Porém, esse bom arranjo entre diferentes culturas não é capaz de suprimir a tensão que se origina da oposição entre uma forma de vida ativa e uma contemplativa. Certamente, Petrarca pode alocar no interior desta última os ensinamentos da cultura pagã, assim como pode insistir em que a primeira deve ser orientada por valores cristãos. Mas, quando se coloca a questão de qual é a melhor forma de vida para o homem, o poeta vai engrossar a fileira dos autores cristãos que defendem a proeminência da vida solitária" (ADVERSE, 2013, p.61).
}

SILVA, Elivanda de Oliveira. A construção do ideário republicano: a vida ativa e a defesa da liberdade. Griot : Revista de Filosofia, Amargosa, Bahia, v.16, n.2, p.236-252, dezembro/2017. 
Essa mudança de paradigma poderá ser sentida com a nova imagem que delineia a cidade: a do cidadão ativo, engajado nos problemas da vida pública. É por isso que nessa época era tão importante ascender a cargos públicos, como o de chanceler. Um desses homens de ação, que marcaram a geração do Quatrocentos, e que teve um papel fundamental no quadro de mudanças que estavam ocorrendo em Florença, além de contribuir para a formação do Republicanismo moderno, foi Coluccio Salutati (1331-1406). Em razão do seu comprometimento cívico, há uma reviravolta nas funções públicas da cidade. Com ele, o cargo de chanceler toma um significado público que até então era desconhecido. Antes, quem ocupava esse cargo era um mero funcionário do palácio, que tinha como tarefa escrever cartas endereçadas aos príncipes. Com Coluccio Salutati, essa perspectiva muda consideravelmente, pois, para ele, ser chanceler não se tratava apenas de ocupar um cargo público, o que o fascinava era o nascimento de um homem público comprometido com seus deveres de cidadão e com sua pátria. No texto Invectiva contra Antonio Loschi de Vicenza, cuja motivação é rebater as calúnias dirigidas ao povo florentino e, por sua vez, defender Florença e suas instituições, constatamos claramente o seu patriotismo.

Sendo cada cidadão um membro de sua cidade e de seu povo e não um
estrangeiro, assumo a causa de minha pátria, aquela que cada um tem a
obrigação de defender, peço àqueles que lerão estas minhas coisas que me
olhem de forma benigna, enquanto discuto pela verdade, pela justiça e
pela pátria (SALUTATI, 2001, p.239).

O Republicanismo, portanto, surge nesse contexto, ou seja, nos remete a uma longa tradição de pensadores que, na Modernidade, remontam, principalmente, ao Humanismo Cívico na Itália Renascentista. Esse movimento de ideias surge em contraposição a um modelo de compreensão de mundo no qual, embora houvesse espaço para a vida prática, tomava a vida contemplativa como instância superior dos homens para pensarem a vida coletiva. Na contramão dessa concepção de mundo, o Humanismo faz do elogio à vida ativa o centro de suas preocupações. $O$ que está em questão é que a realização da vida humana não pode ser alcançada quando não se valorizam as ações dos homens a partir da realidade na qual estão imersos. E esse feito não é possível de ser realizado quando os homens estão sob a tutela de governos despóticos, mas somente em solo republicano.

Em consonância com essa nova forma de vislumbrar o espaço político, podemos dizer que o principal legado do Humanismo para o Republicanismo na Modernidade, foi, portanto, a desconstrução da ideia de que o poder emana de Deus. Essa mudança de perspectiva tem como consequência o retorno da tópica da fundação e da criação das leis na cidade enquanto obra humana. Uma passagem de Cidadania, Historiografia e Republica, de John Pocock, apesar de ser extensa, condensa o argumento que buscamos desenvolver:

O Humanismo cívico assinala um estilo de pensamento no qual se considera que o desenvolvimento do indivíduo, em direção à sua própria realização, só é possível quando este indivíduo age como cidadão, ou seja, como um participante consciente e autônomo de uma comunidade política que autonomamente toma as suas decisões, a pólis ou república. Agora, a

SILVA, Elivanda de Oliveira. A construção do ideário republicano: a vida ativa e a defesa da liberdade. Griot : Revista de Filosofia, Amargosa, Bahia, v.16, n.2, p.236-252, dezembro/2017. 


\begin{abstract}
República - ao contrário do cosmos hierarquizado do pensamento imperial ou monárquico - tinha de ser concebido como finito e localizado no tempo e, portanto, como tendo de apresentar todos os problemas da particularidade. A expectativa que um indivíduo tinha de realização da sua natureza moral e racional, dependia, por conseguinte, da sua capacidade para tomar parte nas decisões políticas, no interior de uma estrutura particularizada e secular, para ser plenamente humano; ele tinha de dominar a política de seu tempo. O pensamento cívico humanista tinha fortemente implícita a noção de que a república e seus cidadãos eram de algum modo capazes deste domínio (POCOCK, 2013, p.21).
\end{abstract}

O ideário republicano que se sobressai do movimento humanista, e que, de certo modo, se faz presente até hoje, consiste em uma proposta de discussão da política a partir da valorização dos negócios humanos que privilegia as preocupações decorrentes de viver em um mundo comum, no qual os homens são os atores principais na cena pública, uma filosofia que encontra suas raízes na concepção ciceroniana de virtude, que já explicitamos anteriormente. $O$ que nos interessa nessa reconstrução do pensamento humanista renascentista é que diante da retomada e valorização de uma série de problemas que dizem respeito à associação e convivência dos homens na cidade, como foi suscitado pelo Humanismo cívico, a questão premente que aparece é como criar uma forma política que garanta aos cidadãos a participação efetiva nos negócios da cidade, descontruindo uma concepção apenas ideal de se conceber a política, de modo distante dos homens.

\title{
Republicanos e Liberais: A liberdade como disputa
}

Certamente, foi com Maquiavel, no século XV, que a concepção republicana de governo atingiu seu auge. Por meio de uma visita à sua obra, especialmente, nos Discursos sobre a primeira década de Tito Lívio, é possível constatar uma formulação original e inovadora que sugere a defesa dos princípios do Republicanismo renascentista. É o que encontramos no segundo capítulo do livro I, quando o autor faz a seguinte afirmação: "Feliz é a República à qual o destino outorga um legislador prudente, cujas leis se combinam de modo a assegurar a tranquilidade de todos, sem que seja necessário reformá-las" (MAQUIAVEL, 2008, p.23), ou ainda, quando o autor associa o crescimento das cidades ao amor dos homens pela liberdade, cuja razão está pautada no bem comum: "não é o interesse particular que faz a grandeza dos Estados, mas o interesse coletivo. E é evidente que o interesse comum só é respeitado nas repúblicas: tudo o que pode trazer vantagem geral é nelas conseguido sem obstáculos (MAQUIAVEL, 2008, p.98).

Contudo, Skinner esclarece que, diferentemente da exaltação desses valores republicanos, na Modernidade, com a ascensão do utilitarismo no século XVIII, e com o uso de princípios utilitaristas para sustentar o Estado Liberal, a teoria dos Estados livres, que fundamenta a liberdade no sentido de autogoverno, caiu cada vez mais em descrédito, e, durante o século XIX, o que se constatou foi o declínio das ideias republicanas (SKINNER, 1999, p.91).

As ideias de participação, igualdade, liberdade, bem comum e virtude cívica foram esvaziadas de sentido, ou, no mínimo, criou-se um outro significado para essas ideias, que não se ajusta a um verdadeiro regime republicano. A fase do Terror, 
liderada pelos Jacobinos, com papel decisivo de Robespierre, o qual é comumente associado ao nome e às ideias de Rousseau ${ }^{8}$, pôs em questão a noção de cidadãos virtuosos autogovernados, um dos princípios mais caros ao Republicanismo deste a Antiguidade.

Em meados do século $\mathrm{XX}$, o cenário de destruição e violência das duas grandes guerras, bem como o horror perpetrado pelo Totalitarismo marcou definitivamente qualquer concepção de política e o interesse dos homens pela vida pública. Numa acepção negativa, a instabilidade política e as consequências desastrosas provocadas pelo Totalitarismo geraram um sentimento de desconfiança e apatia política, porém, de outro lado, em uma vertente positiva, esse mesmo acontecimento fez com que, em meados do século $\mathrm{XX}$, ideias republicanas reaparecem novamente no debate político. Esse novo impulso ao pensamento republicano é explicado em virtude das instituições democráticas liberais não terem conseguido evitar a barbárie provocada pelo Totalitarismo, ou ainda de algumas, através da participação de seus representantes, terem desenvolvido ações que contribuíram com a ascensão desse sistema de governo.

Esse é um movimento interessante de ser destacado porque, embora a concepção republicana não houvesse sido totalmente descartada do vocabulário político, ela raramente era tomada como objeto de investigações rigorosas para pensar os problemas que dizem respeito ao político, como destaca Serge Audier, em seu Les théories de la république. $O$ autor explica que as razões para o esquecimento da tradição republicana podem ser compreendidas em razão do debate sobre os problemas políticos ter sido polarizado entre marxistas e liberais, relegando um segundo plano à referência republicana (AUDIER, 2004, p.3).

O ponto central do Republicanismo e as críticas concernentes a esse modo de pensar a vida pública encontram-se na noção de liberdade. A questão é que, para os pensadores liberais, o mundo moderno é tão diferente do mundo concebido pelos antigos que não comporta mais uma concepção de liberdade política tal como aquela

\footnotetext{
${ }^{8}$ Essa questão causa até hoje uma grande celeuma entre aqueles que estudam o Republicanismo. A identificação entre revolução e terror e a associação às ideias de Rousseau, especialmente do conceito de vontade geral ao de povo como organismo detentor de poder, levou a inúmeras interpretações, não apenas por Robespierre, mas por vários leitores de Rousseau. Sobre isso, Newton Bignotto afirma: "Rousseau de fato criou a linguagem da vontade geral e de sua influência nasceu o recurso "ao povo" como fundamento de todo o poder. Mas esse recurso esteve longe de ser o apanágio dos jacobinos. Ao contrário, ele foi moeda corrente durante a Revolução e seja por isso que o incorruptível pôde lançar mão dele no momento de consolidar seu poder e conduzir a luta contra o que considerava os inimigos do processo revolucionário. Ligar Rousseau a Robespierre por meio do recurso à vontade geral pode levar a crer que havia uma perfeita identidade entre os dois personagens, que acabou por selar o destino da Revolução, o que está longe de ser verdadeiro. Robespierre produziu por meio de suas ações, mas também em seus discursos, uma interpretação das ideias do Genebrino, que não foi certamente a única nem mesmo a única e mesmo a mais influente. Mesmo depois de Termidor, os franceses continuaram a reverenciar a memória do filósofo de Genebra e a ligá-la à luta pela liberdade e não ao Terror e suas terríveis consequências. Isso não quer dizer que a apropriação de suas ideias pelos jacobinos derivasse de um "erro" de leitura. Os escritos de Rousseau foram lidos de várias maneiras e foram apropriados pelos mais diversos grupos políticos, o que não quer dizer que eles não contivessem várias possibilidades de leitura, inclusive aquela dos jacobinos. $\mathrm{O}$ que não nos parece razoável é sugerir um caminho direto entre as ideias do filósofo de Genebra e o comandado por Robespierre como a melhor maneira para se compreender a Revolução francesa e seus limites" (BIGNOTTO, 2011, p. 50-51).
} 
que se encontra na origem da fundação das cidades romana e grega. Esse fosso entre a liberdade dos antigos e a dos modernos foi amplamente aceito, tornando as ideias republicanas inadequadas para os valores modernos nascidos da Renascença e da Reforma. Benjamin Constant expressou essa ideia de forma poderosa e influente em seu pronunciamento, no Athénée Royal de Paris, em 1819, o qual ficou conhecido como Da liberdade dos antigos comparada à dos modernos.

O objetivo dos antigos era a partilha do poder social entre todos os cidadãos de uma mesma pátria. Era isso o que eles chamavam de liberdade. $\mathrm{O}$ objetivo dos modernos é a segurança nos prazeres privados; e eles chamam de liberdade as garantias concedidas pelas instituic,oes a esses prazeres (CONSTANT, 2015, p.286).

O que os cidadãos das antigas repúblicas compreendiam por liberdade era a participação ativa no poder coletivo, mesmo quando se exigia deles o sacrifício de seus interesses privados em prol do bem comum e da autonomia política. Essa era uma exigência impensável para os modernos, pois o que os interessam é o gozo dos prazeres privados.

A independência individual é a primeira das necessidades modernas. Em consequência, jamais é preciso exigir o seu sacrifício para estabelecer a liberdade política. Daí se segue que nenhuma das instituiç̃oes, numerosas e tão alardeadas, que, nas antigas repúblicas embaraçavam a liberdade individual, é admissivel nos tempos modernos (CONSTANT, 2015, p. 92).

As ideias de Constant influenciaram toda uma geração de pensadores ao longo do século XX. Certamente, Isaiah Berlin é um dos nomes em que essa influência se fez mais presente. Em seu famoso ensaio Dois conceitos de liberdade, publicado originalmente em 1958, o autor analisa as concepções de liberdade positiva e negativa, relacionando a primeira ao "autodomínio" e a segunda, à "nãointerferência". A liberdade positiva corresponderia a "estar livre para", enquanto a liberdade negativa corresponderia a "estar livre de" (BERLIN, 1891, p. 142). Vale lembrar, entretanto, que a defesa do autor é pela liberdade negativa, a qual caracteriza a concepção individualista e liberal.

Para Berlin, apenas uma liberdade assegurada pelas leis e que não se oponha aos direitos dos indivíduos pode ser aceita nas sociedades modernas, uma vez que para ele "alguém é livre na medida em que nenhum outro homem ou nenhum grupo de homens interfere nas atividades desse alguém" (BERLIN, 1981, p.136). Nesse sentido, a liberdade política, "é simplesmente a área em que um homem pode agir sem sofrer a obstrução de outros" (BERLIN, 1981, p.136), pois "se sou impedido por outros de fazer o que, de outro modo, poderia fazer, deixo de ser livre" (BERLIN, 1981, p.136).

Se o pressuposto que subjaz a liberdade dos modernos, ou liberdade negativa como também ficou conhecida, é a segurança de privilégios privados, as ideias que constituem o vocabulário republicano, tais como a participação e o engajamento direto dos homens na ação política aparecem como um grande obstáculo ao gozo da independência individual, haja vista que para essa concepção de liberdade "ser livre significa não sofrer interferência dos outros", e "quanto mais ampla a área de não 
interferência, mas ampla minha liberdade" (BERLIN, 1981, p.137). Fica claro, portanto, que a diminuição do desejo de participar da política e dos assuntos coletivos foi uma das formas encontradas pelos pensadores liberais para afirmar os anseios de uma sociedade na qual os interesses privados se sobressaem aos interesses públicos.

A crítica liberal que recai sob a concepção positiva de liberdade expressa por Berlin pode ser apresentada em dois aspectos. $O$ primeiro é que a liberdade positiva ameaça as liberdades individuais, o que abre possibilidade a governos tirânicos e totalitários, nos quais os indivíduos são suprimidos em favor de um "bem maior". Tomada nesse sentido, a liberdade positiva é caracterizada como um ideal altamente intervencionista e até mesmo tirânico, enquanto a liberdade negativa é descrita como um ideal que protege os direitos individuais, porque procura limitar a autoridade pública, ao mesmo tempo em que promove a iniciativa dos cidadãos. $O$ segundo aspecto da crítica é que a liberdade positiva está fundamentada na ideia de que a natureza humana tem uma essência, e que somente será livre aquele que for bem-sucedido na consecução de fins e propósitos determinados por esta essência ${ }^{9}$.

Entretanto, os estudos que surgiram nas últimas décadas por parte dos novos republicanos, quais sejam: Quentin Skinner, John Pocock, Philip Pettit, Maurizio Viroli, apresentam uma concepção de liberdade que vai além dessa dicotomia ${ }^{10}$. Esta terceira concepção seria encontrada na tradição republicana, isto é, nos historiadores e filósofos antigos que exaltam os valores políticos que estão na base da República de Roma (Políbio, Cícero, Tito Lívio), nos humanistas da Renascença italiana que defenderam a liberdade de suas cidades (Salutati), e principalmente nos escritos políticos de Maquiavel.

Quentin Skinner, em Liberdade antes do Liberalismo, esclarece que a liberdade que ressoa no pensamento republicano é aquela que está "associado ao ideal clássico da civitas libera ou do Estado livre" (SKINNER, 1999, p.21). Um Estado, assim como uma pessoa, é livre devido à sua capacidade de autogoverno. Em outras palavras, isso implica que "um Estado livre é uma comunidade na qual as ações do corpo político são determinadas pela vontade dos membros como um todo" (SKINNER, 1999, p.33). Disso segue que, o consentimento e a participação política são princípios essenciais de um governo que visa garantir a liberdade de todos que constituem o corpo político, uma vez que alguém que esteja na condição de dependência, automaticamente perde a capacidade de agir por conta própria e deliberar sobre as ações que constituem uma comunidade livre.

A principal implicação que resulta desse modo de compreender a liberdade é a de que a força ou a coerção não constituem os únicos obstáculos de constrangimentos que interferem na liberdade, tal como preconizam os defensores da concepção liberal

9 Alberto de Barros, no seu livro Republicanismo Inglês, apresenta resumidamente esses aspectos levantados por Isaiah Berlin: "Trata-se de optar por um desses sentidos, fazer a escolha entre uma dessas concepções de liberdade. Como o sentido positivo é pernicioso para os direitos individuais, pois os sacrifica aos destinos do corpo social e abre as portas para regimes totalitários, sendo totalmente inadequado ao pluralismo do mundo contemporâneo, a única forma desejável e inteligível de tratar a liberdade é no seu sentido negativo, que preza a defesa dos direitos individuais" (BARROS, 2015, p.26).

10 Conferir a esse respeito (SKINNER, 1999, p. 62-81); (PETTIT, 1999, p. 21-41); (VIROLI, 2007, p.27-32). 
de liberdade. Para o Republicanismo, o simples fato de viver em uma condição de dependência é uma forma de constrangimento que resulta na perda da liberdade ${ }^{11}$. Dito de outra forma, para a concepção republicana, a liberdade dos cidadãos que constituem um corpo político será garantida quando ninguém estiver sujeito a qualquer vontade, que não a sua, e também quando suas ações estiverem amparadas sobre o império da lei e não de um poder discricionário. Maurizio Viroli explicita com precisão essa ideia, no excerto abaixo:

\begin{abstract}
O republicano sustenta que para realizar a liberdade política é preciso opor-se tanto à interferência e à coerção em sentido próprio quanto à dependência, pela razão de que a condição de dependência é um constrangimento da vontade e, portanto uma violação da liberdade. Isso significa que quem ama a verdadeira liberdade do indivíduo não pode não ser liberal, mas não pode ser apenas liberal. Deve também estar disposto a apoiar programas políticos que tenham por finalidades reduzir os poderes arbitrários que impõem a muitos homens e mulheres uma vida em condição de dependência (VIROLI, 2007, p.28).
\end{abstract}

Partindo do pressuposto de que "só é possível gozar plenamente de liberdade civil como cidadão de um Estado livre" (SKINNER, 1999, p.61), a forma de governo mais adequada seria um "Republicanismo autogovernante", o qual é defendido como "o único tipo de constituição sob a qual a liberdade pública pode ser adequadamente preservada" (SKINNER, 1999, p.54). Aposta bastante diferente da dos liberais, que asseguram que é um erro supor que existe "conexão necessária entre liberdade individual e a norma democrática" (BERLIN, 1981, p.142), visto que a ênfase deles é a área de não-interferência da autoridade pública e não a fonte sob a qual se funda esta autoridade.

Essa terceira via de compreender a liberdade, que aqui designamos de concepção republicana de liberdade, sofreu uma avalanche de críticas pelos pensadores liberais e nunca foi amplamente aceita, pois eles a enxergam como utópica e alegam que o direito de participação como condição para a manutenção da liberdade civil é irrelevante para o mundo político em que vivemos. Contudo, o que se observa, há mais de uma década, é um movimento que busca exatamente apresentá-la como uma alternativa importante para iluminar justamente as temáticas que o liberalismo havia negligenciado: participação política, virtude cívicas, significado de lei, bem comum e a crítica ao individualismo.

O que se percebe claramente é que "o retorno à tradição republicana significa pelo menos o retorno a uma série de debates e à preocupação com a esfera pública, pensada como lugar da efetiva ação dos cidadãos" (BIGNOTTO, 2004, p.18-19). Assim, não apenas com o objetivo de compreender a política a partir de um retorno ao pensamento político clássico, com destaque para o legado do Humanismo cívico, mas na certeza de que é o cidadão o principal protagonista das ações que se efetivam na esfera pública, é que a renovação por temas que configuram o pensamento político republicano ganhou destaque nos debates em torno da filosofia política.

11 Sobre essa questão, Skinner esclarece: "Um Estado ou nação pode ser privado de sua liberdade se for simplesmente sujeito ou propenso a ter suas ações determinadas pela vontade de alguém que não os representes do corpo político como um todo" (SKINNER, 1999, p.33). 


\section{Considerações Finais}

A inspiração de um corpo político que congregue os diversos grupos da sociedade, que tem no direito, na lei e na justiça os seus alicerces principais para defender a liberdade do cidadão contra qualquer poder arbitrários, a qual nos foi legada por Cícero e reafirmada pelos humanistas cívicos, é o caminho que os autores contemporâneos, denominados de novos republicanos, vão perseguir para fazer frente a um modelo de Estado que fundamenta a liberdade dos membros do corpo político numa perspectiva individualista e utilitária. Contrapondo-se a essa perspectiva, há mais de uma década, as pesquisas em torno do Republicanismo foram retomadas e os valores republicanos apontados como apropriados para um modelo de sociedade livre, com ênfase em uma maior participação dos cidadãos na vida pública.. 


\section{Referências bibliográficas}

ADVERSE, Helton Machado. A matriz italiana. In BIGNOTTO, Newton (org). Matrizes do Republicanismo. Belo Horizonte: UFMG, 2013.

ARISTÓTELES. A Política. São Paulo, Martins Fontes, 2006.

AUDIER, Serge. Les théories de la republique. La découverte. Paris, 2004.

BARON, Hans. The Crisis of the Early Italian Renaissance: Civic Humanism and Republican Liberty in an Age of Classicism and Tyranny. Princeton, New Jersey. Princeton University press, 1955.

BARROS, Alberto Ribeiro Gonçalves de. Republicanismo Inglês: uma teoria da liberdade. São Paulo, Discurso Editorial, 2015.

BERLIN, Isaiah. Dois conceitos de liberdade. Brasília, Editora UNB, 1981.

BIGNOTTO, Newton. Maquiavel republicano. São Paulo: Loyola, 1991.

Hannah Arendt e a Revolução Francesa. O que nos faz pensar. Cadernos do departamento de filosofia da PUC-Rio, Rio de janeiro, $\mathbf{n}^{\circ}$ 29, 2011. . Matrizes do Republicanismo. Belo Horizonte: UFMG, 2013.

. Problemas atuais da teoria republicana. IN: CARDOSO, Sérgio. (org.). Retorno ao Republicanismo. Belo Horizonte, UFMG, 2004.

CICERO. Da República. São Paulo: Edipro, 2011.

CONSTANT, Benjamin. A Liberdade dos Antigos Comparada à dos Modernos. São Paulo: Atlas, 2015.

DOVERE, Elio. O Discurso Jurídico e Moral da Utilitas em Roma. In CAILLE, Alain (Org). História argumentada da Filosofia Moral e Política: a felicidade e o útil. São Leopoldo, Editora Unisinos, 2006.

GARIN, Eugênio. Ciência e vida civil no renascimento italiano. São Paulo. Editora da UNESP, 1996. O Homem Renascentista. Lisboa, Editora presença, 1991.

Comentários sobre a primeira década de Tito Lívio. Brasília. Editora UNB,

2008

PETTIT, Philip. Republicanismo - Una Teoria Sobre La Libertad y El Gobierno. Barcelona: Paidos Iberica Ediciones, 1999.

POCOCK, J. C. A. Cidadania, Historiografia e Respublica. Almedina. Coimbra, 2013. POLÍBIO. HISTÓRIAS. Trad. Mário da Gama Kury. Brasília: Ed. UnB, 1996.

PLATÃO. A República. São Paulo: Marins Fontes, 2006.

SALUTATI, Coluccio. Inventiva Contra Antonio Loschi de Vicenza. IN: BIGNOTTO, Newton. Origens do Republicanismo moderno. Belo Horizonte: UFMG, 2001.

SKINNER, Quentin. As fundações do pensamento político moderno. São Paulo: Cia. das Letras, 1996.

. The republican ideal of political liberty. In: BOCK, Gisela (ed.) Machiavelli and Republicanism. Cambridge: Cambridge University Press, 1990.

. Liberdade antes do Liberalismo. São Paulo: UNESP, 1999.

TARANTO, Domenico. A primavera humanista italiana: vida ativa ou contemplativa. In CAILLE, Alain (Org). História argumentada da Filosofia Moral e Política: a felicidade e o útil. São Leopoldo, Editora Unisinos, 2006.

SILVA, Elivanda de Oliveira. A construção do ideário republicano: a vida ativa e a defesa da liberdade. Griot : 
TURSI, Antônio. Cicero. In BARRETO, Vicente de Paulo (Coord.). Dicionário de Filosofia Política. Editora Unisinos: São Leopoldo, 2010.

VIROLI, Maurizio. Direitos e deveres na república: os grandes temas da política e da cidadania. Rio de Janeiro: Elsevier, 2007.

Autor(a) para correspondência: Elivanda de Oliveira Silva, Universidade Federal de Minas Gerais, Faculdade de Filosofia e Ciências Humana, Avenida Antônio Carlos, 6627 - Pampulha, CEP 31270 901, Belo Horizonte - MG, Brasil. elivandaos@gmail.com 